\title{
4 Is it time for a global legal framework in Belgium?
}

\author{
Geert Van Hoorick, ${ }^{1}$ Lise Vandenhende ${ }^{2}$ \\ and Brecht Warnez ${ }^{3}$
}

\section{Mediation in environmental law}

\section{1 'Mediation': one word, different meanings}

Suzanne La Follette, an American author and politician of the first half of the twentieth century, stated, "Laws are felt only when the individual comes into conflict with them". ${ }^{4}$ Despite the intention of the legislators to regulate and avoid conflicts between citizens and between citizens and the government, these conflicts have been present in every period of history. Consequently, in addition to litigation, there is an alternative dispute resolution (ADR). One of the oldest forms of ADR is mediation (consider, for example, the Old Testament or the Laws of Solon). This concept has been used to refer to any kind of third-party intervention, with the aim of moving the parties towards an agreement. Given the lack of legal definition, in this chapter, we use the term in accordance with the prevailing Belgian legal doctrine.

There are two lawyers and three opinions. Thus, in literature, the term 'mediation' has been defined more than once and in different ways. In our opinion, Lien De Geyter formulated the most accurate and comprehensive definition. She describes mediation as

an alternative way to resolve conflicts between two or more persons, based on consensus and with assistance, which is organized by a neutral, impartial and independent third party that does not use any method of coercion, but possesses a right to examine and to make recommendations and tries to reconcile the parties in order to facilitate, structure or coordinate the voluntary search for a solution, and that tries to achieve a lasting solution which

1 Centre for environmental law, University Ghent, Department of European, Public and International Law.

2 Centre for environmental law, University Ghent, Department of European, Public and International Law.

3 Research group for administrative law, University Ghent, Department of European, Public and International Law.

4 La Follette, S., Concerning Women, A. \& C. Boni, New York, 1926, 63. 


\section{Geert Van Hoorick et al.}

the parties have agreed upon voluntarily, because it takes into account the mutual interests and viewpoints. ${ }^{5}$

Defining the concept gives us the ability to demarcate the essential characteristics of mediation. The characteristics of mediation, which are given next, are common elements that have been derived from the different forms of mediation in the various branches of public law (such as the regulations concerning municipal administrative sanctions, the right of education, environmental protection, urban development, social protection, housing, institutional consultation structures between the federal and regional authorities, etc.). ${ }^{6}$ Nevertheless, they do not appear to the same extent for each of these forms of mediation.

In the first place, a voluntary approach is an essential requirement of mediation and its importance cannot be stressed enough. The voluntary approach applies to all of the participants in the mediation procedure. Each party should be able to choose - unrestricted - whether he or she wishes to participate in the mediation procedure and to decide whether mediation can serve his or her interests. Nevertheless, voluntary does not mean absolute permissiveness for the parties. Once they have agreed to start the mediation, the parties must act in good faith. This means that they must make an active and constructive contribution in the search to find a solution (an obligation to perform to the best of one's ability). The voluntariness also implies that a solution can never be imposed by the mediator but rather, it is a result of the agreement between the parties.

Furthermore, mediation differs from most other forms of alternative dispute. This is because the presence of an independent, impartial and neutral third party ('the mediator') is required. The mediator will try to get the dialogue going again. He stimulates a clear communication process and focuses on the interpersonal communication between the parties. A mutual understanding between the parties can arise as a result of formulating their views on the conflict as clearly as possible and actively listening to the views of the other parties. Many conflicts arise from miscommunication. During these discussions, the mediator monitors and promotes equality between the parties.

By listening to the parties and conducting a constructive dialogue with them, the mediator will try to make the parties come to an agreement. It should be taken into account that the conflict is not always strictly legal. Often, emotional interests also play an important part in the struggle between the government and the citizen. In order to reach a sustainable solution, it is important that all of the parties find satisfaction in the result of the mediation.

5 De Geyter, L., “Alternatieve methoden tot beslechting van bestuursgeschillen" (2005) 4 Publiekrechtelijke Kronieken 763.

6 Lancksweerdt, E., "Bemiddeling met en door gemeenten” (2003) 2 Tijdschrift voor Gemeenterecht 103; Santens, M., Gewapend bestuur, die Keure, Bruges, 2005, 173; Lancksweerdt, E., "Bemiddeling in het kader van de wetgeving op de gemeentelijke administratieve sancties: een unieke kans voor de gemeenten" (2005) 1 Tijdschrift voor Gemeenterecht 41. 
Finally, to achieve a successful mediation, the content of the discussions should be confidential. Everything that is said or exchanged (documents, emails, etc.) during mediation is strictly confidential. From the beginning of the mediation process, the parties must agree that everything that is said in the mediation will remain internal and will not be communicated to third parties without mutual agreement. Any potential third party (for example, an expert) is bound by the same confidentiality. The confidential nature of the mediation must be respected during the whole mediation procedure. The mediator is bound by the duty of professional confidentiality and must follow the same rule. This increases the possible effectiveness of mediation because parties can be more open about their interests, goals and potential concessions, without having to fear abuse.

\subsection{Not a matter of administrative law}

Although the concept of mediation between citizen(s) and the government itself was not unknown, mediation, as we know it today, is not reflected in our old laws or even in Napoleon's Code of Civil Procedure (1806). The lack of a legal framework does not mean that all kinds of mediation have been absent from the Belgian area. Mediation has always been available outside of the judicial process and some authors have even sought to provide a basis for the use of mediation during procedures. ${ }^{7}$

In recent decades, mediation has had tremendous success in several branches of Belgian law. The first legislation on mediation in Belgium was introduced in the field of criminal justice. ${ }^{8}$ The modification in 1994 to the Code of Criminal Procedure assigned the possibility for the public prosecutor to propose the mediation procedure in certain criminal cases. Furthermore, mediation appears in social affairs ${ }^{9}$ and in family matters. ${ }^{10}$

Nevertheless, we had to wait until 2005 for the first general mediation regulation in civil procedural law. ${ }^{11}$ Virtue of this law, the Code of Civil Procedure provides for two types of mediation in civil matters: the voluntary mediation and judicial mediation. Anyone who follows this legally prescribed procedure can obtain an executive title. Thus, it has the same force and effect as a judgment. The Act of April 19, 2005, determines the conditions for the recognition of mediators and establishes a federal mediation committee to monitor this recognition procedure. Another act in the same year extends the scope of mediation in

7 Brouwers, S., "Bemiddeling tijdens de procesgang: Is er een wettelijke basis?” (1999-2000) Algemeen Juridisch Tijdschrift 193.

8 Act of February 10, 1994 on regulating the procedure for mediation in criminal cases, Belgian Official Gazette, April 27, 1994.

9 Act of July 5, 1998, on the collective debt settlement and the possibility of sales from the hand of the seized goods, Belgian Official Gazette, July 3, 1998.

10 Act of February 19, 2001, on the procedure mediation in family matters, Belgian Official Gazette, April 3, 2001.

11 Act of February 21, 2005, on amending the Judicial Code in connection with the mediation, Belgian Official Gazette, March 22, 2005. 


\section{Geert Van Hoorick et al.}

criminal affairs by disabling the monopoly of the public prosecutor. ${ }^{12}$ Nowadays, any interested party person may request to start the mediation process during the criminal proceedings.

Meanwhile, taxation mediation has also gained a foothold. The Act of April 25, 2007 , concerning various provisions (IV) ${ }^{13}$ set up a "fiscal mediation service" within the Federal Ministry of Finance. The tax mediation intercedes in disputes between disgruntled taxpayers and tax administration.

The current government has paid particular attention to mediation in its plan of 2015 to reform the judicial organization. ${ }^{14}$ The aim is to give mediation an equal place to the traditional judicial resolution. Unfortunately, no particular attention has been made to mediation in administrative law.

\subsection{The necessity for mediation in environmental practice}

The conclusion that mediation is successful in other branches of law and the formalistic and little pragmatic administrative case law in Belgium has raised the call for mediation in environmental law and administrative law in general. An outstanding example of such a judicial annulment of April 28, 2011, with far-reaching and unintended social consequences is the so-called case 'Tramline Deurne-Wijnegem'. The construction of the tramline was part of Antwerp's master plan to facilitate mobility within and towards the city. Four years after granting the urban permit, the Council of State annulled the permit due to a lack of motivation. ${ }^{15}$ Consequently, the tramline, which was already two-thirds completed, had to be demolished. This meant a loss of 45 million euros for the government. This loss could have been avoided through mediation, since the complainant was not against the idea of the new tramline. He even declared that he was surprised and unhappy about the decision of the Council of State. He had merely intended to establish a dialogue between the government and the neighbourhood about some nuisance problems. Nevertheless, the judgment of the Council of State was final.

Among both politicians and the media, a storm of criticism arose following the strictly legalistic approach of the Council of State, which seemed to have no regard for the social consequences of its judgments. In case law, the Council could not be judged by its critics. After all, the limited suspension and annulment competence of the Council of State was not to be effective for factual dispute resolution. It became clear that administrative mediation can play an important role.

12 Act of June 22, 2005, on introducing provisions on mediation in the Preliminary Title of the Code of Criminal Procedure and the Code of Criminal Procedure, Belgian Official Gazette, April 17, 1878.

13 Art. 116-130 of the Act of April 25, 2007, concerning various provisions (IV), Belgian Official Gazette, May 8, 2007.

14 Minister of Judiciary Koen Geens, The Justice Plan: A More Efficient Judiciary for Justice, available in Dutch at www.stapvoorwaarts.be/wp-content/uploads/2015/03/20150318 Justitieplan-NL.pdf

15 Council of State April 28, 2011, no. 212.825, Lauwers. 
Finally, for the sake of completeness, we should note that not all environmental disputes are suitable for mediation. This is due to the specific characteristics of (Belgian) administrative law such as the unilateral nature of the legal protection, the special protection granted to a third party and legal certainty. For example, a contract that was the result of mediation is not binding to a citizen who was not involved in that mediation. Thus, that citizen can still lodge an appeal for annulment.

In addition, there are still a number of other legal restrictions. Lien De Geyter describes these in detail in her doctoral thesis about ADR. ${ }^{16}$ She argues inter alia that the government cannot freely exercise its powers. Such a restriction stems from the Constitution, on the one hand, and the civil code, on the other. Therefore, the government may not relinquish its competences/powers, and it should exercise these in view of the public interest. As a solution, it is suggested that, in the agreement on the resolution of the dispute, a reservation should be included. This allows a certain commitment of the government, which cannot be deviated without good reason and is in the general interest. Furthermore, the government must always act within the mandatory public law framework. Therefore, it will have to take into account, among other things, the hierarchy of legal norms, the general principles of good governance and the principle of open government. Another important limitation is the scope of mediation in relation to third parties/third stakeholders. Mediation can have an effect on third parties.

Given the rather extensive contribution of De Geyter and others, this Article does not intend to discuss the legal problems and limitations of ADR in administrative law in general. Instead, it aims to focus on the specific case of environmental mediation preceding and during the administrative procedure and preceding and during the judicial procedure.

\subsection{Environmental law in Belgian federalism}

Belgium has a complex political state structure. Unlike the normal origin of a federation, Belgian federalism was caused by the erosion of an original decentralized unitary state. It was not a result of uniting regions. In recent decades, more and more powers have been granted to the regions. Consequently, the Flemish Region, the Brussels-Capital Region and the Walloon Region have the main competences in ambient environmental law sensu latu such as urban planning, environmental protection of the landscape, the protection of the environment, the protection against harmful effects on water and the conservation and protection of nature. ${ }^{17}$ The federal government retains its powers in, for example, the protection against the dangers of ionizing radiation (e.g. nuclear waste) and the protection of the North Sea. Thus, the first consequence of the federal state structure is the different types of mediations in the different regulations. This chapter focuses on the applicable regulations in the Flemish Region.

16 De Geyter, L., Bemiddeling in het bestuursrecht, die Keure, Mechelen, 2006, 365.

17 Art. 6, $\$ 1$, Special Act of August 8, 1980, on institutional reform, Belgian Official Gazette, August 15, 1980. 
The second consequence of the federal structure are the different administrative courts, which each has its own powers and (mediation) procedures. Later, this chapter will give a brief introduction (infra, no. 3.1).

\section{Environmental mediation during the administrative procedure}

\subsection{Different permit procedures, different regulations}

Asking for a permit is a hurdle that almost everyone has to take before carrying out certain urban developments. Article 4.2.1 of the Flemish Zoning Code lists the actions for which a prior environmental permit for urban actions is required. This is a very extensive list, which includes building, rebuilding, renovating, cutting down trees, substantial relief modifications and changing the function of a building. ${ }^{18}$ In addition, Article 4.2.15 of the Flemish Zoning Code requires a prior environmental permit for the parcelling out of land. ${ }^{19}$

There are two different administrative procedures for granting an environmental permit: the regular and the simplified procedure. ${ }^{20}$ Whereas the regular procedure is applicable in the majority of the cases, the simplified procedure is applicable for permit applications for actions listed in Article 17, $\$ 2$ of the Environmental Permit Decree. ${ }^{21}$ During the procedure, an environmental permit has to be submitted with the competent authority (Flemish Government, Provincial Deputation or the Municipal Executive). ${ }^{22}$ The competent authority has to decide within a fixed deadline. ${ }^{23}$ If it refrains from taking a decision within this time limit, the permit application is considered to be declined. ${ }^{24}$ Against this explicit decision or implied decline from the Municipal Executive or the Provincial

18 Maintenance is explicitly released from this duty (see Art. 4.2.1, in fine of the Flemish Zoning Code). Furthermore, Article 4.2.3 of the Flemish Zoning Code provides the possibility for the Flemish Government to make a list of actions that are contemporary or occasionally, or that have a minor spatial impact and are, therefore, exempted of the obligation to receive a prior planning permission. See also the Decision of the Flemish Government of July 16, 2010 , concerning certain the actions for which no planning permission is required, Belgian Official Gazette, December 10, 2010; Van Hoorick, G., Handboek ruimtelijk bestuursrecht, Intersentia, Antwerp, $2011,213$.

19 See Article 4.2.1, $14^{\circ}$ of the Flemish Zoning Code for a definition of parcelling out land. See also Van Hoorick, G., Handboek ruimtelijk bestuursrecht, Intersentia, Antwerp, 2011, 216; Bouckaert, B. and T. De Waele, Ruimtelijke Ordening en Stedenbouw in het Vlaamse Gewest, Vanden Broele, Bruges, 2004, 203.

20 Vanheusden, B., S. Betz, M. Boodts, J. De Coninck, K.J. De Graaf, D. Devos, H.D. Tolsma and K. Van Alsenoy, De omgevingsvergunning: Een eerste analyse, die Keure, Brugge, 2015 , 9-20.

21 Decree of April 252014 concerning the Environmental Permit, Belgian Official Gazette, October 23, 2014 (hereafter, Environmental Permit Decree).

22 Environmental Permit Decree, art. 15.

23 Environmental Permit Decree, art. $32, \$ 1$.

24 Environmental Permit Decree, art. $32, \$ 4$. 
Deputation, an administrative appeal can be lodged respectively with the Provincial Deputation or the Flemish Government. ${ }^{25}$

Against the decisions in administrative appeal and the decision in first instance of the regional environmental development officer or the Flemish government, no further administrative appeal lies - the applicant will have to directly address the Flemish Council for Permit Disputes (see infra, $\mathrm{n}^{\circ} 3.3$ ). ${ }^{26}$

When someone wants to exploit the business premises of noisy or obnoxious trades, a prior environmental permit is also required, as included in classification list in the annex of Decision of the Flemish Government of November 27, 2015, to implement the Environmental Permit Decree (hereafter 'the classification list'). ${ }^{27}$ These establishments differ in nature and size. Some of them can be associated with big firms, such as a petroleum refinery, whereas others are associated with smaller firms (e.g. a pig farm). ${ }^{28}$ The companies that are listed in the classification list are categorized into three classes. Class one represents the business premises of higher noisy or obnoxious trades. Class three represents the business premises of less noisy or obnoxious trades. Whereas for the third class a notification will suffice, for firms in the first or second class, an environmental permit is required. The competent authority (Flemish Government, Provincial Deputation or the Municipal Executive) is determined by the nature of the project. ${ }^{29}$

Against the decision of the Municipal Executive or the Provincial Deputation, an administrative appeal can be lodged, respectively, with the Provincial Deputation or the Flemish Government. ${ }^{30}$ Against the decisions in administrative appeal and the decision in the first instance of the regional environmental development officer or the Flemish Government, no further administrative appeal lies - the applicant will have to directly address the Flemish Council for Permit Disputes (see infra, $\left.\mathrm{n}^{\circ} 3.3\right) .{ }^{31}$

In a densely populated region, such as Flanders, acquiring the required permit is not an easy task. Even the smallest of projects can provoke protest from neighbours or other local residents because they feel that their individual rights are harmed (cfr. the increasing amount of annulment judgments; see the aforementioned). This is reinforced by the fact that, in many cases, for the same project, various permits were required. Before the entry into force of the Environmental

25 Environmental Permit Decree, art. 52.

26 Environmental Permit Decree, art. 52.

27 Decision of the Flemish Government of November 27, 2015, to implement the Decree of April 25, 2014, concerning the environmental permit, Belgian Official Gazette, February 23, 2016.

28 Van Hoorick, G., Handboek ruimtelijk bestuursrecht, Intersentia, Antwerp, 2011, 296.

29 Environmental Permit Decree, art. 15; annex 1 and 2 of the Decision of the Flemish Government of February 13, 2015, of designating the Flemish and Provincial projects to implement the Decree of April 25, 2014, concerning the environmental permit, Belgian Official Gazette, March 4, 2015.

30 Environmental Permit Decree, art. 52.

31 Environmental Permit Decree, art. 52. 
Permit Decree, one could be confronted with the obligation to obtain three different permits. For example, someone who wants to establish and exploit a chemical plant will need an urban permit for building the chemical plant and another environmental permit for the exploitation of the factory. This makes it even more difficult to be in agreement with all of the different parties that are concerned.

However, the Decree of the Flemish Government on April 25, 2014, concerning the ambient environmental permit, consolidates the environmental permit, the urban permit and the subdivision permit into one ambient environmental permit, ${ }^{32}$ it must be emphasized that the decree only concerns the permit procedure. With respect to content, the other decrees (the Flemish Zoning Code and the decree concerning the environmental permit) still apply. ${ }^{33}$

For this reason environmental disputes still occurs and several procedural guarantees exists. The local authority has autonomous discretion that leaves room for policy decisions. First and foremost, it has to take the general interest into account. Additionally, the individual interests of citizens have to be considered. To advance this assessment, mediation between the permit applicant, third parties concerned and any other relevant body of government can be helpful. This mediation can take place before the administrative procedure has started. Furthermore, mediation can even be possible during the administrative procedure.

\subsection{Mediation preceding the procedure for planning permissions}

\subsubsection{The informal mediation}

Obviously, the person who wants to submit a permit application, irrespective of the kind of permit application, can always decide to organize a joint consultation with the competent authority and parties concerned. Especially when it comes to large projects, the initiator of the project can benefit from such an informal meeting. This is because a large number of complaints can be avoided. However, it is difficult to speak in the case of mediation, as usually no neutral mediator is involved. In this case, it is difficult to distinguish mediation from consultation or other forms of participation. Lancksweerdt is of the opinion that mediation occurs when the contact is made according to the principles of mediation, thus with a neutral mediator. In practice, the licensing authority takes this role. The fact that such a procedure is non-binding is not relevant. Moreover, the fact that mediation is initiated before the permit application has the added advantage that one does not have to take procedural stator provisions into account. ${ }^{34}$

32 Since it has entered into force (February 23, 2017), only one application has been submitted and only one decision has be made.

33 Vanheusden, B., ed., De omgevingsvergunning: een eerste analyse, die Keure, Bruges, 2015, 218.

34 Lancksweerdt, E., "Bemiddeling en milieuvergunningen" (2011) 3 Tijdschrift voor Milieurecht 13 . 
The result of informal mediation can be diverse. First of all, it is possible that no permit application is submitted. Secondly, the mediation can result in a private agreement. This agreement can contain certain modalities, according to which the permit applicant will have to submit its permit application. It is also possible that, in this agreement, the competent authority engages himself to grant the permit under the conditions that have been determined in the agreement or that the third parties that are concerned have engaged themselves to not lodge any administrative or judicial appeal. ${ }^{35}$ In this way, mediation can decrease the number of complaints or appeals after the permit is granted and maybe even those that have yet to be executed.

Nonetheless, the outcome of the mediation agreement must be nuanced. In the first place, third parties that are not involved in the mediation can still file a complaint or lodge an appeal during or after the authorization arrangements. Therefore, to ensure legal certainty, it is important to aim to reach and involve all of the concerned parties.

Secondly, the question arises whether the public authority can give up its public power through a private agreement. Informal mediation between private parties does not impose any problems. When the mediation agreement is concluded between a private person (e.g. the initiator of a project) and the public authority, the consequences are less unambiguous. In principle, the powers that are attributed to the administration should be exercised. The administration does not have the power to dispose of these competences and is obliged to apply them in the general interest. The Constitution and the law indicate what powers are attributed and how these should be exercised. They also make clear that no agreement can be made concerning the way an administrative organ exercises its powers. ${ }^{36}$ Consequently, an administrative organ cannot, by means of an agreement, engage itself to take a certain administrative action in the future. It is obliged to take the action that best serves the general interest. If it has bound itself, the organ may no longer be able to make an evaluation at the time that the decision is made. Such restrictions that are imposed on an administrative organ to conclude a private agreement do not imply that a competent authority cannot conclude a private agreement. Furthermore, they do not imply that a public authority can put aside a closed agreement just like that. Only when there is a good reason, the public authority can differ from a private agreement. This way, for example, a local authority that is competent for an environmental permit application can still decide not to grant the permit, even though all of the conditions that have been set out in the private agreement are met, if it has a good reason following from the objections expressed during the public inquiry. ${ }^{37}$

35 Lancksweerdt, E., "Bemiddeling en milieuvergunningen" (2011) 3 Tijdschrift voor Milieurecht 13 .

36 Civil Code, art. 6 and 1128; Belgian Constitution, art. 33.

37 Lancksweerdt, E., "Bemiddeling en milieuvergunningen" (2011) 3 Tijdschrift voor Milieurecht 12; Lancksweerdt, E., "Bemiddeling in het bestuursrecht" in D. Lindemans, ed., Gedogen en bemiddelen in het bestuursrecht, die Keure, Bruges, 2003, 141 and 153. 
To ensure this possibility, the private agreement that results from the mediation should contain the reservation that the authority can bypass the agreement for reasons of general interest. For this reason, in practice, there is rarely a successful informal mediation that precedes the procedure for planning permission.

Given the limitations of the authorization arrangements (infra), preceding mediation is the most efficient. However, in practice, it is not easy to take the decision to use any form of (semi-) mediation before the procedure for planning permissions is started. Usually, problems and conflicts between the planning permission applicant, the government body and/or other stakeholders become clear during the procedure. Therefore, it is appropriate for the initiator of a project to be vigilant and detect possible tensions in advance.

\subsubsection{The project meeting}

As written in Belgian legal doctrine,$^{38}$ the only form of mediation in environmental is the so-called project meeting. Someone who is responsible for the development and implementation of major constructions or building projects ${ }^{39}$ may request a 'project meeting' from the advisory and the licensing authorities, if a realistic project study is available. ${ }^{40}$ The applicant has the right to ask for this project meeting and this request cannot be refused. In this meeting, possible conflicts and tensions are eliminated in advance.

The Environmental Permit Decree provides the possibility for the competent authority to invite third parties on its own initiative or at the request of the initiator. ${ }^{41}$

In our opinion, the project meeting cannot be called mediation. Firstly, it is not a voluntary process, as the concerned authorities cannot refuse the request. Secondly, an independent, impartial and neutral third party (mediator) is not present. Finally, there is no question of equality between the parties, since the concerned authorities also act as the advisory and licensing authorities after the mediation.

\subsection{The mediation during the procedure for planning permissions}

In the procedure for an environmental permit, citizens have the possibility for participation: the so-called public inquiry. ${ }^{42}$ At this stage of the proceedings, anyone can submit objections to the application of the permission. ${ }^{43}$ The licensing

38 Lancksweerdt, E., "Bemiddeling en ruimtelijke ordening” (2010) 60 Tijdschrift voor Ruimtelijke Ordening en Stedenbouw 229.

39 What "major constructions or building projects" is understood to mean is explained in Art. 5 of the decision of the Flemish Government of March 19, 2010 concerning planning certificates, project meetings and urban information, Belgian Official Gazette, April 13, 2010.

40 Environmental Permit Decree, art. 8.

41 Environmental Permit Decree, art. 8, al. 3.

42 Environmental Permit Decree, art. 23.

43 Van Hoorick, G., Handboek ruimtelijk bestuursrecht, Intersentia, Antwerp, 2011, 236 and 298. 
authority is required to take these concerns into account. Despite the possibility of a public inquiry, mediation can be useful. This is because such an inquiry is not intended to adjust the planning permission but rather, aims to assess whether or not to refuse the permission. ${ }^{44}$

Furthermore, in some cases, the Municipal Authority can organize an information meeting within the scope of the public inquiry. For certain class, one business premises, which can have a high impact on the environment or require an environmental impact assessment, an information meeting has to be organized. ${ }^{45}$ However, these instruments can stimulate participation during the procedure. Thus, it is possible that certain conflicts arise during the information meeting. This can be an incentive for the competent authority to organize mediation. ${ }^{46}$

However, the authorization arrangements are not equipped with a procedure for mediation during the administrative procedure. At the same time, informal mediation is not evident. It is very difficult to conduct a profound mediation. This is because the time in which the government must, by law, come to a decision on the permission is too short. ${ }^{47}$ Moreover, there is an important legal principle that states that a permission application may not be fundamentally modified after a public inquiry. ${ }^{48}$ In the event that mediation has succeeded, the permit application can only be modified to a certain extent. Otherwise, the applicant has to renounce its application and file a new application. ${ }^{49}$

For that reason, in practice, we rarely see a successful mediation during the environmental permit procedure. Given the absolute prohibition of changing the permission application after the public inquiry, the essential characteristic of mediation - the search for a satisfactory solution - is completely nullified.

44 More than that, the subject of the permit application cannot be changed during the procedure, especially not after the public inquiry. Otherwise, the public inquiry should be, once again, organized. See, e.g., Council of State, February 21, 2011, no. 211.387; Council of State, November 14, 2013, no. 225.476.

45 Decision of the Flemish Government of November 27, 2015, to implement the Decree of April 25, 2014, concerning the environmental permit, Belgian Official Gazette, February 23, 2016, art. 25; see, e.g., Council of State January 20, 2011, no. 210 532, Naessens, X., "De informatievergadering in de VLAREM-procedure: een gewaarschuwd man is er twee waard" (2014) Tijdschrift voor Omgevingsrecht en Omgevingsbeleid 147.

46 Lancksweerdt, E., "Bemiddeling en milieuvergunningen" (2011) 3 Tijdschrift voor Milieurecht 14 .

47 Act of February 21, 2005, on amending the Judicial Code in connection with the mediation, Belgian Official Gazette, March 22, 2005.

48 See, e.g., Council of State November 28, 2007, no. 177.326, Bernaert; Council of State August 10, 2007, no. 173.955, Carron en Callewaert; Council of State November 19, 2007, no. 172.417, nv Prima; Council of State February 14, 2007, no. 167.789, Collaert; Council of State August 4, 2008, no. 183.773, nv D.M.P.; Council of State, February 21, 2011, no. 211.387, Natuurpunt Oost-Brabant en Haegeman; Council of State, November 14, 2013, no. 225.476, Gemeente Sint-Katelijne-Waver; De Waele, T., P. Flamey, P. Sourbron and P. Jan Vervoort, De milieuvergunning in het Vlaamse Gewest : een overzicht van rechtspraak van de Raad van State, Vanden Broele, Brugge, 2009, 32.

49 Lancksweerdt, E., "Bemiddeling en milieuvergunningen" (2011) 3 Tijdschrift voor Milieurecht 14 . 
However, it is theoretically possible that the permission procedure is stopped as a result of the mediation talks for the applicant to put in an altered planning permission application.

Finally, we should also emphasize that, in this form of (semi-) mediation, there is no question of equivalence between the parties and a neutral mediator is rarely called in.

\section{Environmental mediation during the judicial procedure}

\subsection{A short introduction to the Belgian administrative courts}

In order to comprehend the different kinds of mediation procedures during the various judicial procedures in administrative law, it is necessary to say a few words about the specific organization of administrative courts. This has been shaped by the typical Belgian federal state structure. According to an initial reading of the Belgian Constitution, it is clear that no administrative court can be created other than by an act that is issued by the federal Parliament. ${ }^{50}$ Thus, the Constitution does not explicitly describe the power to establish regional administrative courts for the Flemish Parliament, which is the legislator for the Flemish Community and the Flemish Region.

Nevertheless, through the legal concept of the so-called implied powers, which is contained in Article 10 of the special act regarding the reform of the institutions, it is now accepted that the regions have this power. ${ }^{51}$ Pursuant to the implied powers, states can regulate affairs for which, in principle, they are not authorized, insofar as such provisions are necessary for them to exercise their other attributed powers. The Constitutional Court has judged that these implied powers may be used under three conditions: 1) the exercising of these powers is necessary in order for them to be able to exercise their own powers (those of the regions), 2) it only has a small impact on the federal regulations ${ }^{52}$ and 3 ) the federal regulations are compatible with the differentiated regulation. ${ }^{53}$ One of the uses of those implied powers is the competence for the Flemish Parliament to establish regional administrative courts. The Constitutional Court confirmed this

50 Article 161, introduced in 1993 into the Belgian constitution.

51 See, Special Act Regarding the Reform of the Institutions, art. 10. This is an act that was voted by the federal parliament with a special majority which attributes competences to the Communities and the Regions. See Parl.Doc. Dutch speaking Cultural Council 1973-1974, no. 122/1, 10-21 and Parl.Doc. Chamber of Representatives 1977-1978, no. 461/25, 4).

52 Cf. Constitutional Court September 16, 1998, no. 95/98; Constitutional Court November 28, 1996, no. 68/96; Constitutional Court October 25, 2000, no. 105/200; Constitutional Court October 31, 2000, no. 109/2000; Constitutional Court June 30, 2005, no. $114 / 2005$.

53 Cf. Constitutional Court January 18, 1996, no. 95/98; Constitutional Court November 28, 1996; Constitutional Court October 25, 2000, no. 105/2000. 
competence. ${ }^{54}$ However, the Council of State, which was established at a federal level, continues to act as the cassation court for the regional administrative courts.

Over the last decade, Flanders has created four administrative courts:

- The Council for Permit Disputes is a court where appeals can be made against permit decisions concerning the delivery or refusal of an environmental permit, ${ }^{55}$ a validation decision and a registration decision. ${ }^{56}$

- The Enforcement Counci巨̄ ${ }^{7}$ is an administrative court where an offender can appeal against administrative sanctions in environmental law and spatial planning. ${ }^{58}$

- The Council on Electoral Disputes has the competence on objections to the municipal and provincial elections. ${ }^{59}$

- The Council for disputes about decisions on study progress provides judicial protection for students of higher education colleges and universities in the Flemish Community in disputes on decisions on study progress (e.g. decisions on examinations). ${ }^{60}$

Some Flemish politicians are thinking about having one Flemish administrative court. Given the uncertainty about the compatibility of the power to establish such a common regional administrative court and the theory of implied powers, nowadays, no such legal proposal has been submitted. Last year, however, a general Decree of April 4, 2014, concerning some Flemish administrative courts, was adopted. This tunes the main Flemish administrative courts ${ }^{61}$ to each other and allows a far-reaching cooperation. ${ }^{62}$ Thus, a service for administrative courts has been established where the clerks, legal secretaries and support staff are centralized.

However, the Council of State still plays a part in environmental legislation cases. A cassation appeal to the Council of State is always provided against decisions by the Council for Permit Disputes and the Enforcement Council.

54 Constitutional Court January 27, 2011, no. 8/2011.

55 Environmental Permit Decree, art. 105, $\$ 1$.

56 Flemish Zoning Code, art. 4.8.2, Belgian Official Gazette, August 20, 2009.

57 Before February 23, 2017, this was called the 'Environmental Enforcement Council'. Due to the entry into force of the Environmental Permit Decree, the competences of this court concerning environmental permits were transferred to the Council for Permit Disputes.

58 Flemish Decree of April 5, art. 16.4.19, 1995, concerning general provisions relating to environmental policy, Belgian Official Gazette, June 3, 1995.

59 Flemish Decree of July 8, 2011, art. 203, concerning the organization of the local and provincial elections and amending the municipal Decree of July 15, 2005, the provincial Decree of December 9, 2005, and the Decree of December 19, 2008, concerning the organization of the public centres for social welfare, Belgian Official Gazette, August 25, 2011.

60 Flemish Codification of October 11, 2013, art. II.285 of the decree provisions concerning higher education, Belgian Official Gazette, February 27, 2014.

61 The Council for disputes about decisions on study progress is not included in these regulations.

62 Decree of April 4, 2014, on the organization and procedure of some Flemish administrative courts, Belgian Official Gazette, October 1, 2014. 


\subsection{The Council of State}

\subsubsection{Mediation as a task of magistrates}

The idea of mediation in administrative law was first raised three years ago at parliamentary level. The proposers of these bills attributed a significant role to the magistrates. ${ }^{63}$ In the proposal, the prosecutor could decide to initiate a mediation procedure and he was appointed as the mediator. The choice of the auditor as a mediator is remarkable. Firstly, the independence and impartiality cannot be guaranteed during the mediation assignment or during the judicial assignment. In addition, the confidentiality is put at risk. The parties must be able to show their particular interests, without fear of abuse by the prosecutor during the judicial process. Secondly, the magistrates themselves were against a possible new assignment. This fear is not entirely unjustified. The backlog of court cases in Belgium is still not resolved, and this bill could have the perverse effect that judicial procedures would be longer. Therefore, the bills were never adopted.

\subsubsection{The federal ombudsman as a 'mediator'}

In 2014, the State Council was greatly reformed. One of the key aspects was the introduction of a mediation procedure with the Council of State. The legislator chose to achieve this objective by upgrading the existing institution of the federal Ombudsman. Since the reform of 2014, the procedure before the Ombudsman and the procedure before the Council of State have been linked to each other.

Firstly, the procedure before the Ombudsman continues to run, even if an appeal to the Council of State is pending. Upon the establishment of the Ombudsman, his position was subordinate to any administrative and judicial remedies and the submission and consideration of a complaint to the Ombudsman did not suspend. Since the reform of 2014 , this subordination has been eliminated with regard to the Council of State. Nevertheless, the general principle remains intact. This is that the procedure before the Ombudsman is suspended by lodging an appeal with a court or an organized administrative appeal such as the Council for Permit Disputes, the Enforcement Council or other ordinary tribunals and courts.

Secondly, and more importantly, the period for appeal of the cancellation action by the Council of State has been suspended when a complaint is lodged to the Ombudsman. ${ }^{64}$ The rest of the period for appeal will begin either at the time that the complainant is informed of the decision not to treat his complaint or to reject his complaint, or at the expiry of a period of four months, which starts from the filing of the complaint, if the decision of the Ombudsman did not come

63 Bill to amend the laws of January 12, 1973, at the Council of State, Parl.Doc. Senate 20122013, no. 5-1965/1, 26 p.; Bill to amend the laws on the Council of State, coordinated on January 12, 1973, Parl.Doc. Kamer 2012-2013, no. 2583/001, 30.

64 Council of State Law, art. 19. 
before. In contrast to the period for appeal to the Council for Permit Disputes or the Environmental Enforcement Court, which is not suspended by an Ombudsman procedure, the applicant will always be entitled to a period of 60 days to lodge his appeal before the Council of State, whether he has or has not decided to submit a complaint to the Ombudsman.

The Ombudsman is an important form of alternative dispute resolution (ADR) with great authority in regard to the governments. The Annual Report 2015 of the federal Ombudsman shows that $85.95 \%$ of the valid complaints led to a complete rectification by the government. ${ }^{65}$ Therefore, the upgrading of the Ombudsman as a filter on the access to the Council of State should be praised. Nevertheless, in our opinion, the legislator is wrong when he stated that this type of Ombudsman is a form of mediation.

However, the procedure before the Ombudsman has many features of mediation, which must be nuanced. Firstly, it is generally accepted that voluntariness is an essential feature of mediation. ${ }^{66}$ This means that parties are free to use mediation to resolve their dispute and that they are able to put an end to the mediation at any time. In contrast, the procedure before the Ombudsman is unilaterally initiated by the citizen who files a complaint. ${ }^{67}$ Secondly, the doctrine adopts the equality of the parties as an essential feature of mediation. ${ }^{68}$ As stated earlier, the Ombudsman has great authority. He can send a negative report with recommendations to the minister who acts as higher authority to the concerned government. These recommendations hang like a sword of Damocles over the head of the concerned government. Thirdly, the mediator assists the parties during the mediation procedure without imposing a solution. ${ }^{69}$ The parties have to come to a solution. This is where the shoe pinches for the Ombudsman. Although his recommendations cannot be imposed, the moral pressure is quite large. He is not a guide but an assessor.

Whether the Ombudsman may or may not be interpreted as a form of mediation is purely an academic discussion. However, it is regrettable that the recent reform of the Council of State consists of a non-voluntary, forced complaints procedure with an imbalance between the parties as a method of ADR.

65 See Annual Report 2014. Access: www.federaleombudsman.be

66 Goovaerts, L. and S. Thielemans, Alternatieve geschiloplossing: Bemiddelaars en onderhandelaars aan tafel, Auxis, Brussels, 2000, 361; Hubeau, B., "De bemiddeling in het Publiekrecht" (2000-2001) 11 Rechtskundig Weekblad 410; Lancksweerdt, E., "Bemiddeling met en door gemeenten" (2003) 2 Tijdschrift voor Gemeenterecht 95; Lancksweerdt, E., "Bemiddeling met en door gemeenten" in D. Lindemans, ed., Gedogen en bemiddelen in het bestunrsrecht, die Keure, Bruges, 2003, 141.

67 Art. 8 Act of March 22, 2005, establishing the federal Ombudsmen, Belgian Official Gazette, April 7, 1995; Art. 12 Flemish Decree of July 7, 1998, establishing the Flemish Ombudsman, Belgian Official Gazette, August 25, 1998.

68 De Geyter, L., Bemiddeling in het bestuursrecht, die Keure, Mechelen, 2006, 217; Lancksweerdt, E., "Bemiddeling met en door gemeenten" in D. Lindemans, ed., Gedogen en bemiddelen in het bestuursrecht, die Keure, Bruges, 2003, 141.

69 De Geyter, L., Bemiddeling in het bestuursrecht, die Keure, Mechelen, 2006, 217; Lancksweerdt, E., "Bemiddeling met en door gemeenten" in D. Lindemans, ed., Gedogen en bemiddelen in het bestunrsrecht, di Keure, Bruges, 2003, 141. 


\subsubsection{A new type of (informal) mediation accepted in jurisdiction?}

In contrast to the Council for Permit Disputes (cf. infra), the legislation on the Council of State provides no rules on a judicial referral to an external mediator. Nevertheless, in one case, the Council of State has implicitly allowed the external mediation procedure. ${ }^{70}$ In this case, all of the parties asked spontaneously for a postponement of the case because a solution was sought with the help of a mediator. The Council of State agreed and postponed the case for an undefined period. Although this pragmatic attitude of the Council of State should be praised, the informal nature of this type of mediation has its disadvantages. Firstly, there is no judicial review of the essential characteristics of mediation (e.g. the independence and impartiality of the mediator). Furthermore, the Council of State cannot ratify the mediation agreement.

\subsection{The Flemish Council for Permit Disputes}

The Flemish Parliament has introduced administrative mediation during the procedure for the Council for Permit Disputes by the Decree of July 13, 2012.71 The regulations are now included in the earlier mentioned general Decree of April 4, 2014, concerning some Flemish administrative courts and its administrative decree stating the executory measures. ${ }^{72}$ These provisions state that the Council may refer a dispute to a mediator during the procedure at the joint request of the parties or on the initiative of the court with the agreement of the parties ${ }^{73}$ However, referring to mediation is never an obligation for the Council for Permit Disputes. The start of the mediation procedure suspends the judicial procedure before the Council for Permit Disputes.

The rules provide a lot of possibilities to appoint a mediator: judges, clerks, members of the support staff or even third parties proposed jointly by the parties can be appointed by the Council as mediator. Here, legislation is not required, and there is no applicable jurisdiction available. However, in order to respect the principles of impartiality and independence, it must be assumed that a board member cannot act as a mediator and as a judge in the same case. This would impair the confidentiality of the mediation. It is clear that the parties will attach no credence to the confidentiality of a mediator who can decide as a judge in the case of a failed mediation. In the period between the January, 1, 2014, and January, 1, 2015, the Council for Permit Disputes has referred to mediation nine times; in six other cases the start of mediation failed due to the lack of agreement

70 Council of State November 4, 2014, no. 229.034.

71 Flemish Decree of July 6, 2012, amending various provisions of the Flemish Zoning Code, which concerns the Council for Permit Disputes, Belgian Official Gazette, August 24, 2012.

72 Flemish Decree of April 6, 2014, on the organization and procedure of some Flemish administrative courts, art. 42, Belgian Official Gazette, October 1, 2014; Flemish administrative decree on the procedure of some Flemish administrative courts, art. 95-100, Belgian Official Gazette, May 16, 2014

73 Flemish Council for Permit Disputes October 1, 2013, no. S/2013/0231. 
between the parties ${ }^{74}$ or because to the judge deemed mediation undesirable. ${ }^{75}$ Every time, an internal mediator, especially a clerk, was appointed as mediator. ${ }^{76}$

Unfortunately, the decree provides no special guarantees to ensure the mediation skills of the third party who acts as a mediator. In contrast to Dutch law or the Belgian civil procedure law, Belgium has no specialized committee for recognizing a mediator in administrative matters. It is the Council for Permit Disputes itself that has to ensure the quality, independence and impartiality of the mediator.

The mediation procedure can take up to six months. A successful mediation leads to a settlement that gives more satisfaction to the parties than a judicial procedure. The Council for Permit Disputes can only refuse the ratification of this settlement if the agreement is contrary to public order, to regulations or to the urban development prescriptions. In the absence of a mediation agreement or when the Council for Permit Disputes determines that the preconditions for successful mediation are not or are no longer fulfilled, the Council recommends the continuation of the judicial process.

The Flemish legislator saw the administrative mediation as a filter to avoid jurisdictional procedures. From a preliminary analysis of the small number of case law, it must be concluded that this goal is partly achieved. In five of the nine cases, mediation was successfully completed. ${ }^{77}$ In the four other cases, the parties failed to come to an agreement. ${ }^{78}$ However, it must be noted that in 2016 , more cases

74 Flemish Council for Permit Disputes October 1, 2013, no. S/2013/0231; Flemish Council for Permit Disputes June 9, 2015, no A/2015/0343; Flemish Council for Permit Disputes October 6, 2015, no. RvVb/A/2015/0077; Flemish Council for Permit Disputes October 6,2015 , no. RvVb/S/1516/0071

75 Flemish Council for Permit Disputes May, 25, 2013, no. S/2013/0171; Flemish Council for Permit Disputes May 2013, no. S/2013/0127.

76 Flemish Council for Permit Disputes, January 14, 2014, no. A/2014/0009; Flemish Council for Permit Disputes, January 14, 2014, no. A/2014/0008; Flemish Council for Permit Disputes, June 23, 2015, no. A/2015/0384; Flemish Council for Permit Disputes, August 11, 2015, no. S/2015/0103; Flemish Council for Permit Disputes, October 6, 2015, no. RvVb/A/1516/0094; Flemish Council for Permit Disputes, October 6, 2015, no. $\mathrm{RvVb} / \mathrm{S} / 1516 / 0087$; Flemish Council for Permit Disputes, December 1, 2015, no. $\mathrm{RvVb} / \mathrm{S} / 1516 / 0317$; Flemish Council for Permit Disputes, October 14, 2014, no. A/2014/0705; Flemish Council for Permit Disputes, April 21, 2015, no. A/2015/0250; Flemish Council for Permit Disputes, June 25, 2013, no. S/2013/0171; Flemish Council for Permit Disputes, October 1, 2013, no. S/2013/0231; Flemish Council for Permit Disputes, May 14, 2013, no. S/2013/0127; Flemish Council for Permit Disputes, June 9, 2015, no. A/2015/0343; Flemish Council for Permit Disputes, October 6, 2015, no. $\mathrm{RvVb} / \mathrm{A} / 2015 / 0077$; Flemish Council for Permit Disputes, October 6, 2015, no. $\mathrm{RvVb} / \mathrm{S} / 1516 / 0071$.

77 Flemish Council for Permit Disputes, January 14, 2014, no. A/2014/0009, Flemish Council for Permit Disputes, January 14, 2014, no. A/2014/0008, Flemish Council for Permit Disputes, June 23, 2015, no. A/2015/0384, Flemish Council for Permit Disputes, August 11, 2015, no. S/2015/0103.

78 Flemish Council for Permit Disputes, October 6, 2015, no. RvVb/A/1516/0094, Flemish Council for Permit Disputes, October 6, 2015, no. RvVb/S/1516/0087, Flemish Council for Permit Disputes, December 1, 2015, no. RvVb/S/1516/0317, Flemish Council for 
were referred to mediation; future analyses of this administrative jurisdiction will determine whether or not the introduction of mediation is successful.

\subsection{The Enforcement Council}

The general Decree of April 4, 2014, which concerns some Flemish administrative courts, contains provisions regarding mediation. Unfortunately, they were only made applicable to the Council for Permit Disputes and not to the Enforcement Council. In addition, the special rules for the suspension of the period for appeal when a complaint is lodged to the Ombudsman are not applicable for regional administrative courts. Thus, the Enforcement Council is missing out on mediation.

The only possibility that mediation could be used is similar to the case of the Council of State, which was granted in an informal manner during the mediation process (supra, no. 3.2.3). To this very day, however, it has never happened.

\section{Towards a fully fledged legislation for mediation?}

\subsection{A referring judge}

It appears that mediation in administrative disputes can be an added value for ADR. From the aforementioned, it is clear that neither the Ombudsman nor the judge can be considered to be the most suitable person to act as a mediator in administrative matters (supra). The 'judge as mediator' principle can be problematic because of his duty of confidentiality. This duty does not relieve him of his obligation to declare as a public official, as defined in Article 29 Preliminary Title of the Code of Criminal Procedure. ${ }^{79}$ Furthermore, the inequality of power between the government and citizens provides an additional problem. Unequal power relationships are undesirable in the process of mediation. In order to eliminate these differences, more safeguards will be necessary to add to the existing means of ADR in Belgian administrative law. Unequal power relations between the government and the citizen also cause problems within the scope of a complaint with the Ombudsman. A complaint filed with the Ombudsman can lead to a moral judgment, which the government will want to avoid.

The required impartiality is another factor than can pose a problem. ${ }^{80}$ In this context, the judge, when acting as a mediator, is not allowed to take a decision on the merits of the case if the mediation was unsuccessful. ${ }^{81}$ Otherwise, this can lead to a legal challenge procedure, which cannot be reconciled with the flexibility

Permit Disputes, October 14, 2014, no. A/2014/0705, Flemish Council for Permit Disputes, April 21, 2015, no. A/2015/0250.

79 Parl.Doc. Chamber of Representatives 2003-2004, no. 51-0327/7, 68.

80 See also De Geyter, L., Bemiddeling in het bestuursrecht, di Keure, Mechelen, 2006, 180.

81 Parl.Doc. Chamber of Representatives 2003-2004, no. 327/001, 9; Parl.Doc. Chamber of Representatives 2003-2004, no. 327/007, 53. 
inherent to mediation. ${ }^{82}$ In addition, it should be noted that because of the strict separation of powers, a judge is not allowed to substitute for the administration. However, at the moment, the legislature remains silent in the Judicial Code (for now) ${ }^{83}$ It is regrettable that the Council of Permit Disputes does provide for the possibility for a judge to act as mediator. ${ }^{84}$

Nevertheless, it is not desirable to rule the judge completely out of mediation. In addition to writing a good judgment, the judge needs to find a solution that every party can agree on. This reconciliation is just as important as the settlement of the dispute..$^{85}$ This is why a judge can be of great importance for the courtconnected mediation in administrative disputes through a referral procedure. This model already exists in the judiciary code. Furthermore, several years ago, the Netherlands also introduced the possibility of a 'referral judge'.

In fact, since 2007 (implementation started in 2007), all of the Dutch courts have had a structural referral facility that refers all of the cases that qualify for mediation to a mediation committee. According to this system, a judge can bring the possibilities of mediation, both in civil and administrative cases, to the attention of the parties. However, the use of mediation in administrative disputes has not yet been anchored in the Dutch General Law on Administrative Law (hereafter, 'Awb'). ${ }^{86}$ Currently, only the general Mediation Regulations 2008 of the 'Mediatorsfederatie Nederland' (hereafter, 'MfN') apply. These set out certain rules regarding the procedure, the competence and conduct of the mediator. ${ }^{87}$ To meet the need for a legal framework for mediation, an act was submitted on September $10,2013{ }^{88}$ Although the rules of the MfN would still apply, the act provides for a general obligation in respect of the governing bodies. This bill introduces a competence for judicial referral for both governing bodies ${ }^{89}$ and the

82 Parl.Doc. Chamber of Representatives 2003-2004, no. 51-0327/1, 11.

83 Nothing came of the proposal for a resolution (M. De Schamphelaere, et al.) concerning an improvement of the judicial organization, Parl.Doc. Chamber of Representatives 20082009 , no. 52-1974/001, which argues the necessity of an explicit legal basis for a judge as mediator.

84 Decree of April 4, 2014 on the organization and procedure of some Flemish administrative courts, Belgian Official Gazette, October 1, 2014, art. 42, $\$ 2$.

85 Parl.Doc. Chamber of Representatives 2003-2004, no. 327/007, 51-52.

86 Access: www.wetten.overheid.nl; The Dutch law implementing Directive 2008/52/EC article 3 does provide for a legal basis for judicial referral jurisdiction in cross-border disputes. However, a legal anchoring of mediation and, in particular, the judicial referral system in domestic disputes, including in administrative law, is still missing.

87 These regulations were drawn up by the Dutch Mediation Institute ('NMI'), responsible for the quality of mediation in the Netherlands. Since January 1, 2014, the NMI has been called the "Mediatorsfederatie Nederland (MfN)" (i.e., the association of mediators in the Netherlands). The NMI-regulations were also renamed. Henceforth, the MfN-mediation regulations 2008 have contained the rules on mediation.

88 See www.tweedekamer.nl. The original bill was amended to the recommendation of the Advisory Division of the Council of State, see bill as amended following the recommendation of the Advisory Division of the Council of State, Parl.Doc. Chamber II 2012-2013, 33.727, no. 5 (hereafter, Parl.Doc. Chamber II 2012-2013, 33.727, no. 5).

89 Art. 1, C Parl.Doc. Chamber II 2012-2013, 33.727, no. 5. 
courts. ${ }^{90}$ They are not obliged to refer the parties to mediation but, to a large extent, are urged to do so. It must be emphasized that the parties are under no obligation to try mediation. ${ }^{91}$ It should be noted that this bill was withdrawn, together with two other proposals concerning mediation. ${ }^{92}$ The initiator of the proposal introduced a new, most likely similar, proposal in his capacity of minister for justice and security: the 'law promoting mediation'. ${ }^{93}$ This has been the subject of a public consultation ${ }^{94}$ and is still the subject of much discussion.

As mentioned earlier, such a possibility has also been recently introduced in Belgian law in the procedure before the Council for Permit Disputes (see supra, $\left.\mathrm{n}^{\circ} 3.3\right)$. It is desirable to continue on the same lines in the procedure before the Council of State and other administrative courts. Consequently, at the hearing, or even before the start of the lawsuit, the judge can refer the case to mediation on the common consent of the parties. The actual mediation is left to a specialized and independent mediator.

The question arises as to the duty of the government to consider a mediatory proposal that is made by the court. In light of the principle of solicitude, which is set in Article 3:2 Awb, the Dutch Government can be forced to examine the possibility of mediation. ${ }^{95}$ However, this obligation to examine the possibility of mediation does not automatically entail that the government must agree with the proposal of mediation..$^{96}$

In Belgium, the government also has a duty of care. This implies that the administration can only make a decision on the basis of an adequate and complete examination of the specific case. ${ }^{97}$ Additionally, during the judicial procedures, this duty of care must be observed..$^{98}$ As a result of this, in Belgium, the possibility to introduce a duty to examine the possibility of mediation can also be suggested.

However, this duty to examine whether a referral to mediation is possible will only be effective and consequently applied if the court proceedings can be suspended for the duration of the mediation. In the Netherlands, the suspension

90 Art. 1, F Parl.Doc. Chamber II 2012-2013, 33.727, no. 5.

91 See, e.g., HR January 20, 2006, NJ 2006, 75, LJN AU3724. Nevertheless, it appears that the parties experience a commitment to try mediation, since they are afraid that the court will not appreciate it if he refuses to cooperate. Sponselee, A.J.M., "Mediation: een strategisch verplichte omweg?" (2007) 10 Arbeidsrecht 48.

92 Parl.Doc. Chamber II 2014-2015, $33722, \mathrm{n}^{\circ} 23,33723, \mathrm{n}^{\circ} 14$ and $33727, \mathrm{n}^{\circ} 12$.

93 Wet bevordering mediation.

94 For the concept of the law during public consultation. Access: www.internetconsultatie.nl/ wetmediation.

95 However, this obligation is limited to the relevant facts and interests to be weighed and will play especially if the government's decision has got a discretionary power, see Tolsma, H., Bemiddelend bestuur: Juridische aspecten van bemiddeling bij de bestuurlijke besluitvorming, Boom Juridische Uitgevers, Den Haag, 2008, 38.

96 Tolsma, H., “Mediation in de Algemene wet bestuursrecht: de hoogste tijd?” (2009) 2 Tijdschrift Conflicthantering 17 and 19.

97 See Mast, A., J. Dujardin, M. Van Damme and J. Vande Lanotte, Overzicht van het belgisch administratief recht, Kluwer, Mechelen, 2009, 55.

98 Tijs, R., Algemeen bestuursrecht in hoofdlijnen, Intersentia, Antwerp, 2012, 264. 
of the judicial procedure already applies when the parties use mediation with a registered mediator. ${ }^{99}$ Additionally, in Belgian civil law ${ }^{100}$ and in the procedure before the Council for Permit Disputes, the period of limitation is suspended when mediation is initiated. ${ }^{101}$ This is not yet the case when a complaint is filed with the Ombudsman (supra $\mathrm{n}^{\circ}$ 3.2.2) or in cases where mediation is used ad hoc. ${ }^{102}$ Nevertheless, it would be desirable to introduce the suspension of the judicial procedure for mediation in all administrative matters.

In spite of all the advantages, in the parliamentary debate, the argument was put forward that the European Court for Human Rights (ECHR) had already condemned Belgium by reason of a violation of Article 6 of the ECHR. ${ }^{103}$ At the basis of this condemnation was the fact that the administrative courts do not handle court cases within a reasonable time, as Article 6 of the ECHR imposes. This argument is nevertheless irrelevant because this reasonable period of time must be assessed in the light of the specific circumstances. ${ }^{104}$ In this context, the Dutch Council of State considers that mediation should not be included in the determination of the reasonable time. ${ }^{105}$

In addition, Article 13 of the ECHR gives everyone the right to an effective remedy before a national authority in order to safeguard, among others, the rights that are contained in Article 6 of the ECHR. The requirement of an effective legal remedy before a national body should not be interpreted as the requirement of a judicial authority. All of the procedures that are available in a specific state will play a role in assessing whether the requirement of Article 13 has been fulfilled. Here, accessibility, as well as speed and the guarantee of an effective solution, will be taken into consideration. ${ }^{106}$ Consequently, mediation can also fall within the scope of this requirement. Mediation is accessible,

99 MfN Mediation Regulations 2008, art. 9.1. Additionally, the draft of the Mediator Registry Act provides for an interruption of the procedure by the administrative court, see Kamerstukken II 2012-2013, 33.727, no. 6, 13.

100 Judicial Code, art. 1731, $\$ 3$. See also Gayse, B., B. Allemeersch and P. Schollen, "De wet van 21 februari 2005 in verband met bemiddeling" in B. Allemeersch, ed., De nieuwe wet op bemiddeling, die Keure, Mechelen, 2005, 9 and 40.

101 Art. 42 Decree of April 4, 2014 on the organization and procedure of some Flemish administrative courts.

102 Art. 19, third paragraph Act of the Council of State, as amended by Art. 7, $3^{\circ}$ Act of January 19,2014, on the reform of the power, the control process and the organization of the State Council, Belgian Official Gazette, February 3, 2014; It is most regrettable that a pending judicial proceeding is not suspended when the parties decide to start mediation (or file a complaint with the Ombudsman). Due to this, mediation becomes a parallel dispute resolution, rather than an alternative dispute resolution, which was the initial purpose of introducing mediation.

103 Draft law on the reform of the power, the control process and the organization of the State Council, Parl.Doc. Senate 2013-2014, no. 5-2277/3, 18.

104 Frydlender t. Frankrijk, 30979/96, \$86, EHRM 2000-VII; Pizzati t. Italië, 62361/00, $\$ 134,29$ maart 2006.

105 Dutch Council of State December 2, 2011, JB 2012/257; Dutch Council of State January 16, 2013, Jurisprudence Environmental Law 2013/311.

106 Doran t. Ierland, 50389/99, \$\$55-60, ECHM 2003-X. 


\section{Geert Van Hoorick et al.}

cost-effective and fast, which implies that this alternative form of dispute resolution will safeguard the rights that are contained in Article 6, rather than violate them. A limitation in time for the use of the mediation will further contribute to this. By analogy with the Netherlands and the Judicial Code, ${ }^{107}$ a maximum period for mediation in administrative matters can be an additional guarantee for compliance with Article 6 of the ECHR. ${ }^{108}$

\subsection{A general mediation committee with recognized mediators}

For the sake of both structurally and emotionally unequal power relations, a neutral mediator in administrative disputes is needed. Additionally, in the Netherlands, the Mediator Registry Act provides a legal basis for the rules on registration. ${ }^{109}$ According to these rules, the mediator must meet the demands of quality and integrity. In Belgium, a regulation like in the Netherlands does not yet exist. However, in order for mediation to be effective, a recognized mediator is desirable, if not needed. When a mediator can be any neutral third party designated by the parties, this does not offer enough guarantees concerning the relationship between administration and citizens. A recognized mediator, on the other hand, can be guaranteed as a professional, impartial and independent third party. Therefore, a recognized mediator can be the outstanding means to rectify the unequal power relations in administrative matters, without losing sight of the intended purpose of mediation. ${ }^{110}$ Therefore, when introducing a general referral system for the court, it can be recommended to set up a general mediation committee. All of the disputes that are eligible for mediation can be referred to the mediation committee by the court. In turn, the Committee can refer the dispute to a recognized mediator, who is specialized in the specific matter. He subsequently handles the dispute. The recognition of the mediators proceeds through a flexible procedure, which is based on some predefined conditions. This already happens in both the Netherlands and Belgian civil judicial law. ${ }^{111}$

The administrative procedure is merely focused on participation such as the public inquiry. Therefore, mediation will play a less important role during the

107 Belgian Judicial Code, art. 1734, $\$ 2$

108 The mediation procedure before the Council of Permit Disputes already has a maximum duration of six months (Council for Permit Disputes Procedural Rules, art. 42, first paragraph, $4^{\circ}$ ).

109 Bill from the member Van der Steur to lay down the rules concerning the registration and promotion of the quality of mediators (Mediator Registry Act), Parl.Doc. Chamber II 2012-2013, 33.722, no. 5 (hereafter, Parl.Doc. Chamber II 2012-2013, 33.722, no. 5 ). Bill from the member Van der Steur to lay down the rules concerning the registration and promotion of the quality of mediators (Mediator Registry Act), Parl.Doc. Chamber II 2012-2013, 33.722, no. 6, 13 (explanatory memorandum); Also this bill was withdrawn, see $\mathrm{n}^{\circ} 0$ in fine.

110 See De Geyter, L., Bemiddeling in het bestuursrecht, die Keure, Mechelen, 2006, 128.

111 Additionally, in the mediation procedure before the Council for Permit Disputes, there are some conditions set out. However, no recognition is needed yet. 
administrative procedure (see supra, $\mathrm{n}^{\circ} 2.3$ ). Consequently, a legislative framework for mediation preceding or during the administrative procedure is not as necessary as it is for mediation during the judicial procedure. However, if the parties decide on an informal mediation in this stage, they should be able to address the mediation committee and make use of a recognized mediator.

\section{Conclusion}

All of the aforementioned makes it entirely clear that, for the sake of mediation as a form of ADR, a central mediation committee, including recognized mediators, is needed. Judges in both civil and administrative matters can refer to this body with a view to mediation. An independent, neutral mediator, who is recognized by the central mediation committee on the basis of general conditions, can lead the deliberation. Meanwhile, the basic principles of mediation, such as confidentiality and voluntariness, can be guaranteed.

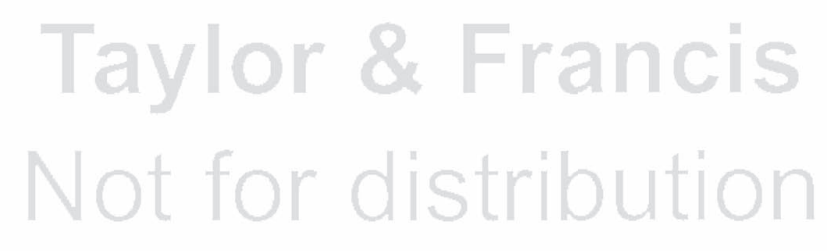

